\title{
電子情報通信学会 情報・システムソサイエティ誌編集委員会
}

\author{
•副会長（編集会議担当） \\ •編集委員長 \\ ・編集幹事 \\ •特任編集幹事
}

-企画広報幹事

・和文論文誌編集副委員長

・英文論文誌編集副委員長

\author{
和田 親宗 \\ 坪下幸寛 \\ 大塚 真吾 \\ 日置 尋久 \\ 菅谷 史昭 \\ 松居 辰則 \\ 宮崎 修一 \\ 門田 啓 \\ 篠崎 隆宏 \\ 林 良一 \\ 神原誠之 \\ 金子 晴彦 \\ 寺尾 真 \\ (九工大wada@brain.kyutech.ac.jp) \\ （富士ゼロックス Yukihiro.Tsuboshita@fujixerox.co.jp） \\ （神奈川工科大 otsuka@ic.kanagawa-it.ac.jp） \\ (京大 hioki.hirohisa.2x@kyoto-u.ac.jp) \\ (マインドワード fsugaya@mindword.jp) \\ （早大 matsui-t@waseda.jp） \\ (京大 shuichi@media.kyoto-u.ac.jp) \\ (NEC monden@nec.com) \\ (東工大 shinot@ict.e.titech.ac.jp) \\ (NTT ryoichi.hayashi@hco.ntt.co.jp) \\ (奈良先端大 kanbara@is.naist.jp) \\ (東工大 kaneko@c.titech.ac.jp) \\ (NEC m-terao@nec.com) \\ 吉本 潤一郎（奈良先端大 juniti-y@is.naist.jp） \\ 山田浩史（東京農工大 hiroshiy@cc.tuat.ac.jp）
}

・編集委員

(研究専門委員会)

・ME とバイオサイバネティックス (MBE)

・ライフインテリジェンスとオフィス情報システム (LOIS)

・画像工学 (IE)

・言語理解とコミュニケーション (NLC)

・コンピュータシステム (CPSY)

・コンピュテーション (COMP)

-人工知能と知識処理 $(\mathrm{AI})$

・ソフトウェアサイェンス (SS)

・データ工学 (DE)

・パターン認識・メディア理解 (PRMU)

・ディペンダブルコンピューティング (DC)

・ニューロコンピューティング (NC)

・知能ソフトウェア工学 (KBSE)

・音声 $(\mathrm{SP})$

・教育工学 (ET)

- 医用画像 (MI)

・ソフトウェアインタプライズモデリング (SWIM)

・リコンフィギャラブルシステム (RECONF)

・情報論的学習理論と機械学習 (IBISML)

・マルチメディア情報ハイディング・エンリッチメント (EMM)

・クラウドネットワークロボット (CNR)

・サービスコンピューティング (SC)

(特別研究専門委員会)

・サイバーワールド $(\mathrm{CW})$

・減災情報システム（DRIS）

・サステナブルコンピューティング (SUSC)
堀瀬 友貴（東京女子医大 horise.yuki@twmu.ac.jp）
渡部 智樹（NTT tomoki.watanabe.cd@hco.ntt.co.jp）
海野 恭平 (KDDI 総合研究所 ky-unno@kddi-research.jp)
坂地 泰紀（東大 sakaji@sys.t.u-tokyo.ac.jp）
木村睦（龍谷大 mutsu@rins.ryukoku.ac.jp）
脊戸 和寿（成蹊大 seto@st.seikei.ac.jp）
太田 唯子（富士通研 yuiko@jp.fujitsu.com）
島和之（広島市立大 shima@hiroshima-cu.ac.jp）
大塚 真吾（神奈川工科大 otsuka@ic.kanagawa-it.ac.jp）
田村 雅人（日立 masato.tamura.sf@hitachi.com)
金子 晴彦（東工大 kaneko@c.titech.ac.jp）
神原 裕行（東工大 hkambara@hi.pi.titech.ac.jp）
木村 功作（富士通研 kimura.kosaku@fujitsu.com）
小橋川哲（NTT satoshi.kobashikawa.he@hco.ntt.co.jp）
大沼亮（福島大 onuma@sss.fukushima-u.ac.jp）
大竹 義人 (奈良先端大 otake@is.naist.jp)
五月女 健治（法政大 saotome@hosei.ac.jp）
佐藤 真平（東工大 satos@ict.e.titech.ac.jp）
森永 聡（NEC mori-chin@nec.com）
日置 尋久（京大 hioki.hirohisa.2x@kyoto-u.ac.jp）
神原 誠之(奈良先端大 kanbara@is.naist.jp)
細野繁（東京工科大 hosonosgr@stf.teu.ac.jp）
河野 義広（東京情報大 ykawano@rsch.tuis.ac.jp）
山下倫央（北大 tomohisa@complex.ist.hokudai.ac.jp）
上原 稔（東洋大 uehara@toyo.jp）

編集後記 $\nabla$ 寄稿者の皆様と編集委員の皆様のおかげで，面白い紙面となりました，皆様に心より感謝致し ます。また，貴重な経験ができる編集委員ですので，今後に読者の皆様に編集委員の依頼がきたときには， ぜひ快くお受け下さい.（主担当 木村）初めて副担当の仕事をさせて頂きました. 主担当の木村先生, 執 筆者, 編集委員, 幹事の皆様に支援頂き, 副担当の仕事を進めることができました. このような貴重な経験 をさせて頂いた皆様に感謝致します。（副担当 坂地） 